\title{
PENGARUH SISTEM REWARD DAN MOTIVASI KARYAWAN TERHADAP KINERJA KARYAWAN
}

\author{
Taufan Maulana Fajri ${ }^{1}$, Abdul Rohman ${ }^{2}$ \\ ${ }^{1}$ STIE Muhammadiyah Jakarta, taufanmaulana7@yahoo.com \\ ${ }^{2}$ STIE Muhammadiyah Jakarta, bdhurz_adhe29@yahoo.com
}

\begin{abstract}
ABSTRAK
Penelitian ini bertujuan untuk menganalisis pengaruh sistem reward dan motivasi karyawan terhadap kinerja karyawan. Penelitian ini menggunakan pendekatan sensus, dimana semua anggota populasi dijadikan sebagai responden dengan jumlah 36 karyawan PT. Wahyu Tehnik Utama. Analisis data menggunakan analisis regresi berganda dengan terlebih dahulu melakukan uji asumsi klasik. Hasil penelitian menunjukkan bahwa terdapat pengaruh positif sistem reward dan motivasi karyawan terhadap kinerja karyawan. Hal ini menunjukkan bahwa semakin baik sistem reward dan motivasi kerja karyawan maka kinerja karyawan akan meningkat secara optimal.
\end{abstract}

Kata Kunci : System Reward, Motivasi, Kinerja.

\begin{abstract}
This study aims to analyze the effect of reward systems and employee motivation on employee performance. The sample obtained was 36 respondents, the sampling technique uses probability sampling, which is a sampling technique that provides equal opportunities for each element (member) of the population to be selected as sample members. . This study uses a census approach, where all members of the population serve as respondents with 36 employees of PT. Wahyu Tehnik Utama. The results showed that there was an effect of the reward system on employee performance. This proves the hypothesis which states that there is a significant influence between the reward system on employee performance and employee motivation has a significant effect on employee performance.
\end{abstract}

Keywords: Reward, Motivation, Performance

\section{PENDAHULUAN}

Prasetya dan Kato (2011) mengemukakan kinerja adalah hasil yang dicapai dari setiap kegiatan yang dilakukan dengan kemampuan karyawan yang bekerja di situasi apapun. Faktor pertama yang mempengaruhi kinerja karyawan adalah reward. Robbins (2009) menyatakan bahwa salah satu cara untuk memotivasi karyawan adalah dengan memberikan reward. Menurutnya reward adalah penghargaan yang diberikan kepada karyawan sebagai bentuk apresiasi terhadap kinerjanya. Untuk mengantisipasi berbagai hambatan yang dialami oleh pihak manajemen tersebut, diperlukan adanya pemberian reward serta motivasi kerja yang mendukung bagi karyawan. Reward dan motivasi kerja merupakan salah satu faktor penting, sebab dengan adanya reward dan motivasi kerja yang mendukunglah yang dapat meningkatkan kinerja karyawan sehingga pencapaian tujuan yang telah ditetapkan perusahaan dapat tercapai.

Pemberian reward sangat berpengaruh terhadap kinerja dalam kualitas kinerja karyawan. Pada umumnya, dengan adanya posisi atau jabatan-jabatan yang dimiliki seseorang kerap kali mengharapkan upah yang sesuai. Akan tetapi adapula yang beranggapan dengan posisi atau 
jabatan yang telah dimiliki sudah merasa nyaman dengan kondisi tersebut. Suatu gambaran pemberian reward bagi karyawan seperti yang terjadi di PT. Wahyu Tehnik Utama di Jakarta. Dimana pelaksanaan reward ini masih rendah namun tidak sedikit dari karyawan yang masih loyal dan nyaman bekerja hingga bertahun-tahun lamanya.

Simamora (2014) menyatakan upaya menciptakan sumber daya manusia perusahaan yang handal, salah satu aspek yang harus diperhatikan perusahaan adalah motivasi kerja karyawan. Motivasi adalah sebuah fungsi pengharapan individu bahwa upaya tertentu menghasilkan kinerja yang pada gilirannya membuahkan imbalan yang dikehendaki. Arifin et al (2014) membuktikan bahwa motivasi berpengaruh positif terhadap kinerja karyawan.

Brown (2009) mengungkapkan bahwa motivasi karyawan berkaitan dengan tingkat kinerjanya. Titik awal peningkatan motivasi ini dapat dilakukan dengan memberikan reward yang dapat berupa intrinsik reward yaitu reward yang merupakan bagian yang datang dari pekerjaan itu sendiri dan lebih berupa kepuasan pribadi untuk mencapai sesuatu yang berharga seperti tanggung jawab, tantangan, otonomi, tujuan atau imbalan berbentuk pujian yang diberikan serta ekstrinsik reward yang merupakan penghargaan atau imbalan yang diperoleh dari luar pekerjaan seperti bonus, insentif, tunjangan atau penghargaan lain yang bersifat nyata serta imbalan yang diberikan oleh orang lain. Reward sebagai salat satu motivasi dari kebijakan pimpinan akan berdampak terhadap peningkatan kinerja karyawan (Jayanti \& Wati, 2019).

Berdasarkan uraian latar belakang tujuan penelitian ini adalah untuk menguji pengaruh sistem reward dan motivasi karyawan terhadap kinerja karyawan pada PT. Wahyu Tehnik Utama.

\section{KAJIAN LITERATUR}

\section{Konsep Teori Hierarki Kebutuhan Abraham Maslow}

Konsep hierarki kebutuhan dasar ini bermula ketika Maslow melakukan observasi terhadap perilaku monyet. Berdasarkan pengamatan, didapatkan kesimpulan bahwa beberapa kebutuhan lebih diutamakan dibandingkan dengan kebutuhan yang lain. Kebutuhan maslow memiliki 5 tingkatan, yakni:

1. Kebutuhan Fisiologis

Kebutuhan fisiologis merupakan kebutuhan paling dasar yang lebih berhubungan pada kebutuhan fisik, seperti kebutuhan makanan, minuman, tempat berteduh, seks, tidur, dan oksigen. Kebutuhan fisiologi merupakan kebutuhan yang memiliki potensi besar untuk menuju ke tingkat kebutuhan berikutnya.

2. Kebutuhan akan rasa aman

Setelah kebutuhan fisiologis sudah terpenuhi, maka ada kebutuhan rasa aman, seperti rasa aman fisik, stabilitas, ketergantungan, perlindungan, dan kebebasan dari berbagai ancaman, teroris, penyakit, takut, cemas, atau bencana alam.

3. Kebutuhan Sosial

Setelah dua kebutuhan di atas terpenuhi, selanjutnya akan muncul kebutuhan akan rasa memiliki-dimiliki dan kasih sayang. Manusia akan mencari sahabat, pasangan, keturunan, dan kebutuhan untuk dekat dengan keluarga. Seseorang yang cintanya sudah relatif terpenuhi tidak akan merasa panik ketika menolak cinta dan ketika ada seseorang yang menolak dirinya, ia juga tidak merasa hancur.

4. Kebutuhan akan penghargaan

Setelah tiga kebutuhan di atas terpenuhi, manusia akan mengejar kebutuhan akan penghargaan, seperti menghormati orang lain, status, ketenaran, reputasi, perhatian, dan sebagainya. Menurut Maslow, kebutuhan akan penghargaan juga terbagi atas dua tingkatan, yaitu tingkatan yang rendah dan tinggi. Tingkatan rendah yaitu kebutuhan untuk menghormati orang lain, kebutuhan status, ketenaran, reputasi, perhatian, apresiasi, martabat, dan dominasi. Kebutuhan yang tinggi ialah kebutuhan harga diri seperti perasaan, keyakinan, kompetensi, prestasi, penguasaan, kemandirian, dan kebebasan.

5. Kebutuhan akan aktualisasi diri 
Kebutuhan aktualisasi diri merupakan tingkatan kebutuhan yang paling tinggi. Kebutuhan ini melibatkan keinginan yang terus-menerus untuk mencapai potensi. Menurut Maslow, kebutuhan ini ialah kebutuhan yang dimiliki manusia untuk melibatkan diri sendiri untuk menjadi apa yang sesuai keinginannya berdasarkan kemampuan diri.

\section{Sistem Reward}

Reward atau penghargaan meliputi banyak dari perangsang yang disediakan oleh organisasi untuk karyawan sebagai bagian dari kontrak psikologis. Penghargaan juga memuaskan sejumlah kebutuhan yang berusaha untuk dipenuhi oleh karyawan melalui pilihan mereka atas perilaku terkait pekerjaan (Moorhead dan Griffin, 2013).

\section{Motivasi}

Sunyoto (2013) berpendapat bahwa motivasi adalah bagaimana cara mendorong semangat kerja seseorang agar mau bekerja secara optimal guna mencapai tujuan organisasi. Motivasi dapat juga diartikan faktor penting yang mendorong orang untuk bertindak dengan cara tertentu.

\section{Kinerja}

Kinerja karyawan atau performance sebagai suatu gambaran mengenai hasil atau tingkat keberhasilan dalam suatu pelaksanaan kegiatan dalam pencapaian tujuan, visi dan misi organisasi yang dituangkan melalui perencaaan strategis suatu organisasi. Kinerja dapat diketahui apabila kita telah menetapkan suatu tolak ukur, dengan adanya tolak ukur kinerja seseorang dapat diketahui tingkat keberhasilannya (Moeheriono, 2010).

\section{Pengembangan Hipotesis dan Kerangka Pikir}

Wijayanti dan Aldila (2016) dengan penelitiannya yang berjudul "Pengaruh Penghargaan dan Motivasi Terhadap Kinerja Karyawan" menyatakan bahwa penghargaan berpengaruh signifikan terhadap kinerja karyawan. Hasil tersebut menunjukkan bahwa hipotesis yang pertama yaitu :terdapat pengaruh pernghargaan terhadap kinerja karyawan" terbukti kebenarannya. Hasil penelitian ini didukung oleh penelitian yang telah dilakukan oleh Hidayat (2018) yang menyatakan bahwa hasil dari penelitian ini menunjukkan bahwa reward berpengaruh positif dan signifikan terhadap kinerja karyawan. Selain itu, hasil penlitian juga didukung oleh penelitian yang dilakukan oleh Irawanti (2016) dimana pemberian reward berpengaruh positif dan signifikan terhadap kinerja pegawai. Yang artinya, bahwa gaji, bonus, perhatian dan pujian adalah alat yang dapat digunakan oleh manajer untuk memotivasi karyawannya dengan tujuan untuk membuat kinerja menjasi efektif dan efisien.

Hasil penelitian sebelumnya yang dilakukan oleh Wijayanti dan Aldila (2016), Hidayat (2018), Irawanti (2016) menyatakan bahwa sistem reward berpengaruh positif terhadap kinerja karyawan. Berdasarkan uraian tersebut, maka dibuat hipotesis pertama yaitu:

\section{X1: Sistem reward berpengaruh positif terhadap kinerja karyawan}

Penelitian sebelumnya yang dilakukan oleh Wijayanti dan Aldila (2016), diperoleh hasil bahwa motivasi berpengaruh signifikan dan positif terhadap kinerja karyawan. Yang berarti bahwa semakin tinggi motivasi akan meningkatkan kinerja karyawan. Hasil penelitian ini juga didukung oleh penelitian yang dilakukan oleh Kurnia (2016) yang menyatakan bahwa ada pengaruh positif antara motivasi dan kinerja dengan pencapaian prestasi, artinya karyawan yang mempunyai motivasi tinggi cenderung mempunyai kinerja tinggi. Maka pemberian motivasi bagi karyawan itu sangat penting diberikan oleh atasan.

Hasil penelitian sebelumnya yang dilakukan oleh Wijayanti dan Aldila (2016) dan Kurnia (2016) menyatakan bahwa motivasi karyawan berpengaruh positif terhadap kinerja karyawan. Berdasarkan uraian tersebut, maka dibuat hipotesis kedua yaitu:

X2: Motivasi karyawan berpengaruh positif terhadap kinerja karyawan 
Berikut 1 berikut ini menjelaskan kerangka pikir penelitian

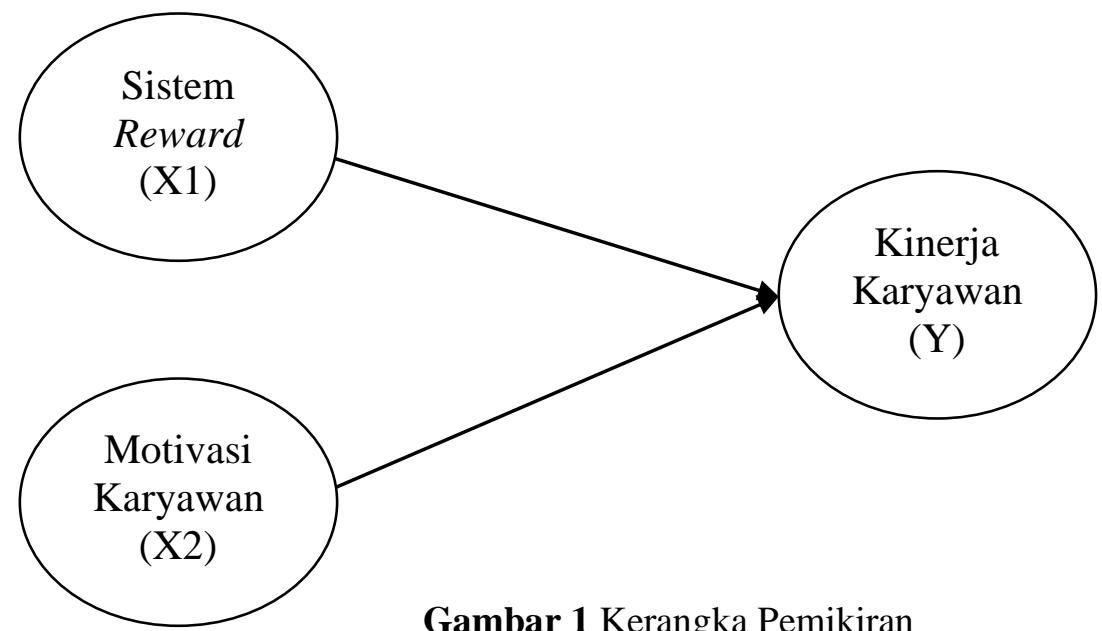

Gambar 1 Kerangka Pemikiran

\section{METODE PENELITIAN}

Sampel dalam penelitian ini adalah seluruh karyawan PT. Wahyu Tehnik Utama yang berjumlah 36 responden.

Tabel 1. Operasional Variabel

\begin{tabular}{|c|c|c|}
\hline Variabel & Konsep Variabel & Indikator \\
\hline $\begin{array}{l}\text { Sistem } \\
\text { Reward } \\
(\mathrm{X} 1)\end{array}$ & $\begin{array}{l}\text { Reward atau penghargaan meliputi banyak dari } \\
\text { perangsang yang disediakan oleh organisasi untuk } \\
\text { karyawan sebagai bagian dari kontrak psikologis. } \\
\text { Penghargaan juga memuaskan sejumlah kebutuhan } \\
\text { yang berusaha untuk dipenuhi oleh karyawan } \\
\text { melalui pilihan mereka atas perilaku terkait } \\
\text { pekerjaan. }\end{array}$ & $\begin{array}{l}\text { a. Pencapaian } \\
\text { b. Penyelesaian } \\
\text { c. Gaji } \\
\text { d. Upah }\end{array}$ \\
\hline $\begin{array}{l}\text { Motivasi } \\
\text { Karyawan } \\
(\mathrm{X} 2)\end{array}$ & $\begin{array}{l}\text { Motivasi adalah bagaimana cara mendorong } \\
\text { semangat kerja seseorang agar mau bekerja secara } \\
\text { optimal guna mencapai tujuan organisasi. }\end{array}$ & $\begin{array}{l}\text { a. Pekerjaan yang } \\
\text { menantang } \\
\text { b. Menjadi contoh bagi } \\
\text { pegawai lain } \\
\text { c. Pengendalian } \\
\text { pekerjaan } \\
\text { d. Afiliasi dengan rekan } \\
\text { kerja }\end{array}$ \\
\hline $\begin{array}{l}\text { Kinerja } \\
\text { Karyawan } \\
(\mathrm{Y})\end{array}$ & $\begin{array}{l}\text { Kinerja atau prestasi kerja adalah hasil atau tingkat } \\
\text { keberhasilan seseorang secara keseluruhan selama } \\
\text { periode tertentu didalam melaksanakan tugas } \\
\text { dibandingkan dengan berbagai kemungkinan seperti } \\
\text { standar hasil kerja, target atau sasaran atau kriteria } \\
\text { yang telah ditentukan terlebih dahulu dan disepakati } \\
\text { bersama }\end{array}$ & $\begin{array}{ll}\text { a. Jumlah pekerjaan } \\
\text { yang telah } \\
\text { diselesaikan } \\
\text { b. Menetapkan target } \\
\text { pekerjaan } \\
\text { c. Bekerja sesuai } \\
\text { prosedur } \\
\text { d. Dedikasi dalam } \\
\text { bekerja }\end{array}$ \\
\hline
\end{tabular}


Berdasarkan gambar model penelitian di atas, kemudian diterjemahkan ke dalam bentuk persamaan sebagai berikut :

Keterangan :

$$
\mathrm{Y}=\alpha+\beta 1 \mathrm{X} 1+\beta 2 \mathrm{X} 2+\mathrm{e}
$$

$\mathrm{Y}=$ Variabel dependen dalam hal ini kinerja karyawan

$\alpha \quad=$ Nilai konstanta

$\beta 1=$ Koefisien regresi variabel independen (X1)

$\beta 2=$ Koefisien regresi variabel independen (X2)

$\mathrm{X} 1=$ Variabel independen dalam hal ini sistem reward

$\mathrm{X} 2=$ Variabel independen dalam hal ini motivasi karyawan

e $\quad=$ Margin error

Pengujian hipotesis dilakukan dengan menggunakan uji signifikansi dan membandingkan t-tabel dengan t-statistik (Wati, 2018)

\section{PEMBAHASAN}

\section{Analisis Deskripsi}

Pada tahapan ini akan dilakukan analisis terhadap variabel-variabel penelitian berdasarkan item pertanyaan dalam kuesioner. Deskripsi dari variable-variabel penelitian tersebut dijelaskan pada tabel 2 sebagai berikut

Tabel 2. Deskripsi Penelitian

\begin{tabular}{|c|c|c|c|c|c|c|c|c|c|c|c|}
\hline \multirow{2}{*}{$\begin{array}{c}\text { Variabel dan } \\
\text { Indikator }\end{array}$} & \multicolumn{2}{|c|}{1} & \multicolumn{2}{|c|}{2} & \multicolumn{2}{|c|}{3} & \multicolumn{2}{|c|}{4} & \multicolumn{2}{|c|}{5} & \multirow{2}{*}{ Mean } \\
\hline & $\mathbf{F}$ & $\%$ & $\mathbf{F}$ & $\%$ & $\mathbf{F}$ & $\%$ & $\mathbf{F}$ & $\%$ & $\mathbf{F}$ & $\%$ & \\
\hline \multicolumn{11}{|c|}{ Sistem Reward (X1) } & 4.206 \\
\hline $\mathrm{X} 1.1$ & 0 & 0 & 0 & 0 & 0 & 0 & 31 & 31.3 & 5 & 5.1 & 4.139 \\
\hline $\mathrm{X} 1.2$ & 0 & 0 & 0 & 0 & 0 & 0 & 25 & 25.3 & 11 & 11.1 & 4.306 \\
\hline $\mathrm{X} 1.3$ & 0 & 0 & 0 & 0 & 1 & 1.0 & 31 & 31.3 & 4 & 4.0 & 4.083 \\
\hline $\mathrm{X} 1.4$ & 0 & 0 & 0 & 0 & 1 & 1.0 & 27 & 27.3 & 8 & 8.1 & 4.194 \\
\hline $\mathrm{X} 1.5$ & 0 & 0 & 0 & 0 & 0 & 0 & 6 & 6.1 & 30 & 30.3 & 4.833 \\
\hline $\mathrm{X} 1.6$ & 0 & 0 & 0 & 0 & 9 & 9.1 & 25 & 25.3 & 2 & 2.0 & 3.806 \\
\hline $\mathrm{X} 1.7$ & 0 & 0 & 0 & 0 & 0 & 0 & 19 & 19.2 & 17 & 17.2 & 4.472 \\
\hline $\mathrm{X} 1.8$ & 0 & 0 & 0 & 0 & 0 & 0 & 35 & 35.4 & 1 & 1.0 & 4.028 \\
\hline $\mathrm{X} 1.9$ & 0 & 0 & 0 & 0 & 1 & 1.0 & 34 & 34.3 & 1 & 1.0 & 4.000 \\
\hline \multicolumn{11}{|c|}{ Motivasi Karyawan (X2) } & 4.100 \\
\hline $\mathrm{X} 2.1$ & 0 & 0 & 0 & 0 & 9 & 9.1 & 26 & 26.3 & 1 & 1.0 & 3.778 \\
\hline $\mathrm{X} 2.2$ & 0 & 0 & 0 & 0 & 11 & 11.1 & 25 & 25.3 & 0 & 0 & 3.694 \\
\hline $\mathrm{X} 2.3$ & 0 & 0 & 0 & 0 & 23 & 23.2 & 11 & 11.1 & 2 & 2.0 & 3.417 \\
\hline $\mathrm{X} 2.4$ & 0 & 0 & 0 & 0 & 6 & 6.1 & 26 & 26.3 & 4 & 4.0 & 3.944 \\
\hline $\mathrm{X} 2.5$ & 0 & 0 & 0 & 0 & 1 & 1.0 & 19 & 19.2 & 16 & 16.2 & 4.417 \\
\hline $\mathrm{X} 2.6$ & 0 & 0 & 0 & 0 & 0 & 0 & 9 & 9.1 & 27 & 27.3 & 4.750 \\
\hline $\mathrm{X} 2.7$ & 0 & 0 & 0 & 0 & 0 & 0 & 26 & 26.3 & 10 & 10.1 & 4.278 \\
\hline $\mathrm{X} 2.8$ & 0 & 0 & 0 & 0 & 0 & 0 & 17 & 17.2 & 19 & 19.2 & 4.528 \\
\hline \multicolumn{11}{|c|}{ Kinerja Karyawan (Y) } & 4.145 \\
\hline Y.1 & 0 & 0 & 0 & 0 & 1 & 1.0 & 27 & 27.3 & 8 & 8.1 & 4.194 \\
\hline Y.2 & 0 & 0 & 0 & 0 & 0 & 0 & 24 & 24.2 & 12 & 12.1 & 4.333 \\
\hline Y.3 & 0 & 0 & 0 & 0 & 0 & 0 & 10 & 10.1 & 26 & 26.3 & 4.722 \\
\hline Y.4 & 0 & 0 & 0 & 0 & 0 & 0 & 34 & 34.3 & 2 & 2.0 & 4.056 \\
\hline Y.5 & 0 & 0 & 0 & 0 & 0 & 0 & 34 & 34.3 & 2 & 2.0 & 4.056 \\
\hline
\end{tabular}




\begin{tabular}{|l|l|l|l|l|l|l|l|l|l|l|l|}
\hline $\begin{array}{l}\text { Variabel dan } \\
\text { Indikator }\end{array}$ & \multicolumn{2}{|c|}{$\mathbf{1}$} & \multicolumn{2}{|c|}{$\mathbf{2}$} & \multicolumn{3}{|c|}{$\mathbf{3}$} & \multicolumn{3}{|c|}{$\mathbf{4}$} & \multicolumn{2}{|c|}{$\mathbf{5}$} & \multirow{2}{*}{ Mean } \\
\cline { 2 - 14 } & $\mathbf{F}$ & $\mathbf{\%}$ & $\mathbf{F}$ & $\mathbf{\%}$ & $\mathbf{F}$ & $\mathbf{\%}$ & $\mathbf{F}$ & $\mathbf{\%}$ & $\mathbf{F}$ & $\mathbf{\%}$ & \\
\hline Y.6 & 0 & 0 & 0 & 0 & 0 & 0 & 35 & 35.4 & 1 & 1.0 & 4.028 \\
\hline Y.7 & 0 & 0 & 0 & 0 & 0 & 0 & 35 & 35.4 & 1 & 1.0 & 4.028 \\
\hline Y.8 & 0 & 0 & 0 & 0 & 0 & 0 & 36 & 36.4 & 0 & 0 & 4.000 \\
\hline Y.9 & 0 & 0 & 0 & 0 & 0 & 0 & 25 & 25.3 & 11 & 11.1 & 4.306 \\
\hline Y.10 & 0 & 0 & 0 & 0 & 0 & 0 & 36 & 36.4 & 0 & 0 & 4.000 \\
\hline Y.11 & 0 & 0 & 0 & 0 & 1 & 1.0 & 31 & 31.3 & 4 & 4.0 & 4.083 \\
\hline Y.12 & 0 & 0 & 0 & 0 & 3 & 3.0 & 32 & 32.3 & 1 & 1.0 & 3.944 \\
\hline
\end{tabular}

Berdasarkan tabel diatas, item-item pertanyaan variabel pertama yaitu Sistem Reward memiliki mean sebesar 4.206 yang berarti memiliki kecenderungan positif. Variabel kedua yaitu Motivasi Karyawan memiliki mean sebesar 4.100 yang berarti memiliki kecenderungan positif. Kemudian variabel ketiga yaitu Kinerja Karyawan yang memiliki mean sebesar 4.145 yang juga berarti memiliki kecenderungan positif.

\section{Uji Validitas}

Untuk menguji dari suatu data penelitian dapat menggunakan analisis pearson correlation dimana jika total dari analisis menunjukkan nilai $<0,05$ maka data dikatakan valid.

\section{Hasil Uji Validitas Variabel Sistem Reward (X1)}

Tabel 2. Hasil Uji Validitas Variabel Sistem Reward (X1)

\begin{tabular}{|c|c|c|c|c|}
\hline Indikator & $\mathbf{r}_{\text {tabel }}$ & $\mathbf{r}_{\text {hitung }}$ & $\begin{array}{c}\text { Signifikan } \\
\alpha\end{array}$ & Keterangan \\
\hline $\mathrm{X} 1.1$ & 0.3291 & 0.731 & 0,000 & Valid \\
\hline $\mathrm{X} 1.2$ & 0.3291 & 0.827 & 0,000 & Valid \\
\hline $\mathrm{X} 1.3$ & 0.3291 & 0.804 & 0,000 & Valid \\
\hline $\mathrm{X} 1.4$ & 0.3291 & 0.580 & 0,000 & Valid \\
\hline $\mathrm{X} 1.5$ & 0.3291 & 0.421 & 0,011 & Valid \\
\hline $\mathrm{X} 1.6$ & 0.3291 & 0.463 & 0,004 & Valid \\
\hline $\mathrm{X} 1.7$ & 0.3291 & 0.687 & 0,000 & Valid \\
\hline $\mathrm{X} 1.8$ & 0.3291 & 0.673 & 0,000 & Valid \\
\hline $\mathrm{X} 1.9$ & 0.3291 & 0.644 & 0,000 & Valid \\
\hline
\end{tabular}

Sumber: Hasil Olah Data Program SPSS

Dari hasil uji validitas variabel sistem reward dengan menggunakan SPSS 22 terhadap 36 responden dapat diambil kesimpulan bahwa semua item pernyataan tersebut memiliki nilai $r$ hitung $>\mathrm{r}$ tabel dan nilai signifikansi $\mathrm{p}$-value lebih kecil dari 0,05. Sehingga semua item pernyataan tersebut dapat digunakan dalam penelitian ini (valid).

\section{Hasil Uji Validitas Variabel Motivasi Karyawan (X2)}

Table 3. Hasil Uji Validitas Variabel Motivasi Karyawan (X2)

\begin{tabular}{|c|c|c|c|c|}
\hline Indikator & $\mathbf{r}_{\text {tabel }}$ & $\mathbf{r}_{\text {hitung }}$ & $\begin{array}{c}\text { Signifikan } \\
\boldsymbol{\alpha}\end{array}$ & Keterangan \\
\hline $\mathrm{X} 2.1$ & 0.3291 & 0.796 & 0,000 & Valid \\
\hline $\mathrm{X} 2.2$ & 0.3291 & 0.782 & 0,000 & Valid \\
\hline $\mathrm{X} 2.3$ & 0.3291 & 0.797 & 0,000 & Valid \\
\hline $\mathrm{X} 2.4$ & 0.3291 & 0.713 & 0,000 & Valid \\
\hline $\mathrm{X} 2.5$ & 0.3291 & 0.668 & 0,000 & Valid \\
\hline
\end{tabular}




\begin{tabular}{|c|c|c|c|c|}
\hline X2.6 & 0.3291 & 0.580 & 0,000 & Valid \\
\hline X2.7 & 0.3291 & 0.644 & 0,000 & Valid \\
\hline X2.8 & 0.3291 & 0.531 & 0,000 & Valid \\
\hline
\end{tabular}

Sumber: Hasil Olah Data Program SPSS

Dari hasil uji validitas variabel motivasi karyawan dengan menggunakan SPSS 22 terhadap 36 responden dapat diambil kesimpulan bahwa semua item pernyataan tersebut memiliki nilai rhitung > rtabel dan nilai signifikansi p-value lebih kecil dari 0,05. Sehingga semua item pernyataan tersebut dapat digunakan dalam penelitian ini (valid).

\section{Hasil Uji Validitas Variabel Kinerja Karyawan (Y)}

Tabel 4. Hasil Uji Validitas Variabel Kinerja Karyawan (Y)

\begin{tabular}{|l|l|l|l|l|}
\hline \multicolumn{1}{|c|}{ Indikator } & \multicolumn{1}{c|}{$\mathbf{r}_{\text {tabel }}$} & \multicolumn{1}{c|}{$\mathbf{r}_{\text {hitung }}$} & $\begin{array}{c}\text { Signifikan } \\
\alpha\end{array}$ & Keterangan \\
\hline Y.1 & 0.3291 & 0.679 & 0,000 & Valid \\
\hline Y.2 & 0.3291 & 0.770 & 0,000 & Valid \\
\hline Y.3 & 0.3291 & 0.503 & 0,002 & Valid \\
\hline Y.4 & 0.3291 & 0.611 & 0,000 & Valid \\
\hline Y.5 & 0.3291 & 0.424 & 0,010 & Valid \\
\hline Y.6 & 0.3291 & 0.538 & 0,001 & Valid \\
\hline Y.7 & 0.3291 & 0.713 & 0,000 & Valid \\
\hline Y.8 & 0.3291 & 0.387 & 0,020 & Valid \\
\hline Y.9 & 0.3291 & 0.483 & 0,003 & Valid \\
\hline Y.10 & 0.3291 & 0.647 & 0,000 & Valid \\
\hline Y.11 & 0.3291 & 0.762 & 0,000 & Valid \\
\hline Y.12 & 0.3291 & 0.571 & 0,000 & Valid \\
\hline
\end{tabular}

Sumber: Hasil Olah Data Program SPSS

Dari hasil uji validitas variabel kinerja karyawan dengan menggunakan SPSS 22 terhadap 36 responden dapat diambil kesimpulan bahwa semua item pernyataan tersebut memiliki nilai rhitung > rtabel dan nilai signifikansi p-value lebih kecil dari 0,05. Sehingga semua item pernyataan tersebut dapat digunakan dalam penelitian ini (valid).

\subsubsection{Uji Realibilitas}

Dalam penelitian suatu variabel dikatakan cukup reliabel bila variabel tersebut mempunyai nilai construct reliability lebih besar dari 0,6 . Berikut ini adalah tabel hasil pengujian reliabilitas pada masing-masing variabel penelitian.

Tabel 5. Hasil Uji Reliabilitas

\begin{tabular}{|l|l|l|l|}
\hline \multicolumn{1}{|c|}{ Variabel } & \multicolumn{1}{c|}{$\begin{array}{c}\text { Cronbach } \\
\text { Alpha }\end{array}$} & $\begin{array}{c}\text { Standar } \\
\text { Reliabilitas }\end{array}$ & Keterangan \\
\hline Sistem Reward & 0,817 & 0,7 & Reliabel \\
\hline Motivasi Karyawan & 0,844 & 0,7 & Reliabel \\
\hline Kinerja Karyawan & 0,818 & 0,7 & Reliabel \\
\hline
\end{tabular}

Sumber: Hasil Olah Data Program SPSS

Dari hasil uji reliabilitas semua variabel, diperoleh nilai-nilai Cronbach Alpha dari semua variabel penelitian ini menunjukkan lebih besar dari nilai 0,7 maka demikian jawaban-jawaban responden dari variabel-variabel penelitian tersebut reliabel, sehingga dapat digunakan untuk penelitian selanjutnya.

\section{Uji asumsi klasik}


Hasil uji asumsi klasik menunjukan bahwa uji normalitas terpenuhi, dengan menggunakan uji statistik non-parametrik Kolmogorov-Smirnov (K-S) yang mana kriteria suatu data residual berdistribusi normal yaitu nilai Asymp. Sig. (2-tailed) >0,05 dan hasil menunjukan bahwa data dalam penelitian ini berdistribusi normal karena nilai nya Kolmogorov-Smirnov $>0.05$ yaitu 0.133. kemudian untuk uji multikolinieritas hasil nya menunjukan bahwa antara variabel sistem reward dan motivasi karyawan tidak berkorelasi atau multikolinieritas tidak terjadi dalam model penelitian karena diperoleh nilai VIF lebih kecil dari 10 yaitu 1.57 untuk variabel sistem riward dan motivasi karyawan. Hasil uji heteroskedastisitas menunjukan bahwa tidak terjadi heteroskedastisitas karena terlihat pada titik-titik yang menyebar secara acak diatas dan dibawah angka nol (0) dan tidak membentuk suatu pola tertentu, maka dapat dikatakan bahwa regresi tidak mengalami ganguan heteroskedastisitas sehingga model regresi layak dipakai untuk memprediksi kinerja kerja berdasarkan masukan variabel bebas

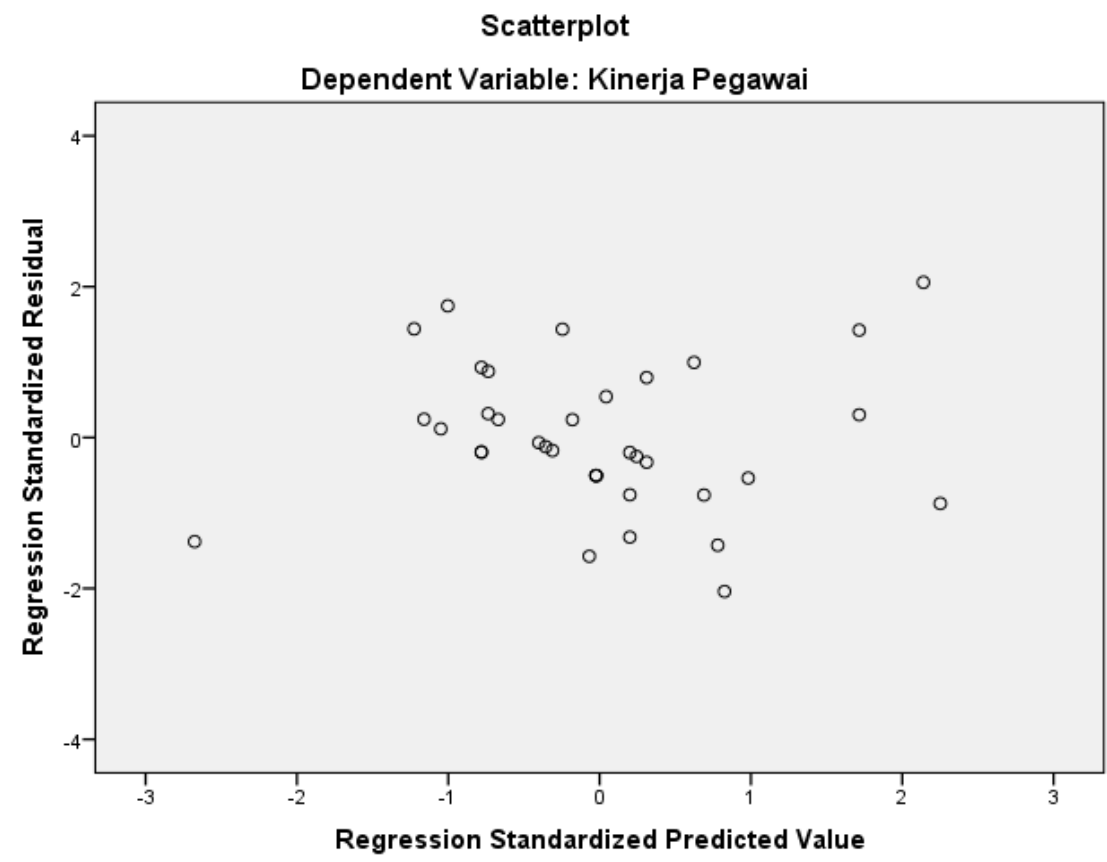

\section{Analisis Regresi}

Gambar 4.4

Scatterplot

Hasil dari analisa regresi yang dilakukan menunjukan model penelitian sebagai berikut:

$$
\mathrm{Y}=21.288+0.549 \mathrm{X}_{1}+0.228 \mathrm{X}_{2}+\mathrm{e}
$$

Dengan hasil uji signifikan koefisiensi (Uji t) menyatakan bahwa harga berpengaruh secara signifikan terhadap minat beli, lalu nilai sig untuk kualitas produk $0,043<0,05$ maka kualitas produk memiliki pengaruh secara signifikan terhadap minat beli. Adapun juga nilai Koefisien Regresi Terstandarisasi (Beta) terbesar dimiliki oleh variabel harga yaitu sebesar 0,398, hal ini menunjukkan bahwa variabel harga memiliki pengaruh paling besar terhadap minat beli hal ini ditunjukan dengan tabel sebagai berikut: 


Tabel 4.14
Hasil Uji t (Parsial)
Coefficients

Sumber: Hasil Olah Data Program SPSS

Berdasarkan hasil uji t (parsial) pada model regresi, diperoleh nilai t hitung sebesar 3.938 dan nilai signifikansi variabel sistem reward sebesar $0.000<0.05$ (taraf signifikansi 5\%). Artinya dapat disimpulkan bahwa secara parsial variabel sistem reward berpengaruh signifikan terhadap kinerja karyawan.

Berdasarkan hasil uji t (parsial) pada model regresi, diperoleh nilai t hitung sebesar 2.050 dan nilai signifikansi variabel motivasi karyawan sebesar $0.048<0.05$ (taraf signifikansi 5\%). Artinya dapat disimpulkan bahwa secara parsial variabel motivasi karyawan berpengaruh signifikan terhadap kinerja karyawan.

Hasil Uji Koefisien Determinasi $\left(\mathbf{R}^{2}\right)$

Nilai koefisien determinasi ditunjukkan oleh nilai $\mathrm{R}^{2}$ dari model regresi digunakan untuk mengetahui besarnya variabilitas variabel dependen yang dapat dijelaskan oleh variabel-variabel bebasnya. Berdasarkan hasil analisis didapatkan hasil sebagai berikut :

\section{Tabel 4.15}

Hasil Uji Koefisien Determinasi $\left(\mathbf{R}^{2}\right)$
\begin{tabular}{|l|l|l|l|l|}
\hline Model Summary \\
Model & $\mathrm{R}$ & R Square & $\begin{array}{l}\text { Adjusted } \\
\text { Square }\end{array}$ & $\begin{array}{l}\text { Rtd. Error of } \\
\text { the Estimate }\end{array}$ \\
\hline 1 & $.764^{\mathrm{a}}$ & .584 & .558 & 1.783 \\
\hline
\end{tabular}

Sumber: Hasil Olah Data Program SPSS

Berdasarkan tabel diatas menunjukkan bahwa nilai Adjusted $\mathrm{R}^{2}$ sebesar 0.558 yang berarti bahwa variabilitas variabel kinerja karyawan yang dapat dijelaskan oleh variabel sistem reward dan motivasi karyawan sebesar 55.8\%. Sedangkan sisanya sebesar $44.2 \%$ dijelaskan oleh faktor lain yang tidak disertakan dalam penelitian ini.

\section{Pengaruh Sistem Reward terhadap Kinerja Karyawan}

Hasil penelitian menunjukkan bahwa ada pengaruh sistem reward terhadap kinerja karyawan. Hal ini dibuktikan dengan statistik $t_{\text {hitung }}$ sebesar 0.549 dengan signifikansi sebesar 0.000 . Oleh karena nilai siginifikansi lebih kecil dari $0.05 \quad(0.000<0.05)$ maka penelitian ini berhasil membuktikan hipotesis yang menyatakan bahwa terdapat pengaruh signifikan antara sistem reward terhadap kinerja karyawan. Hasil penelitian ini mendukung hipotesis yang pertama dimana terdapat pengaruh positif dan siginifikan sistem reward terhadap kinerja karyawan.

Hal ini sejalan dengan penelitian yang didokumentasikan (Wijayanti dan Aldila (2016), Hidayat (2018), Irawanti (2016)) yang menunjukkan bahwa sistem reward berpengaruh positif dan singnifikan terhadap kinerja karyawan.

\section{Pengaruh Motivasi Pegawai Terhadap Kinerja Karyawan}

Hasil penelitian menunjukkan bahwa ada pengaruh motivasi karyawan terhadap kinerja karyawan. Hal ini dibuktikan dengan statistik $t_{\text {hitung }}$ sebesar 0.228 dengan signifikansi sebesar 
0.048. Oleh karena nilai siginifikansi lebih kecil dari $0.05(0.048<0.05)$ maka penelitian ini berhasil membuktikan hipotesis yang menyatakan bahwa terdapat pengaruh signifikan antara motivasi karyawan terhadap kinerja karyawan. Hasil penelitian ini mendukung hipotesis yang pertama dimana terdapat pengaruh positif dan siginifikan terhadap kinerja karyawan.

Hal ini sejalan dengan penelitian yang didokumentasikan Wijayanti dan Aldila (2016) dan Kurnia (2016) yang menunjukkan bahwa motivasi pegawai berpengaruh positif dan singnifikan terhadap kinerja karyawan.

\section{PENUTUP}

Berdasarkan hasil penelitian melalui analisis secara empiris sistem reward berpengaruh positif dan signifikan terhadap kinerja karyawan, artinya semakin baik perusahaan membuat sistem rewart maka kinerja karyawan akan meningkat Analisis secara parsial membuktikan bahwa motivasi karyan berpengaruh signifikan terhadap kinerja, artinya semakin tinggi karyawan termotivasi maka kinerja karyawan akan semakin meningkat.

Keterbatasan penelitian ini digunakan penelitian sangat terbatas karena singkatnya waktu untuk menyebar angket kuisioner dan mendapat responden yang tepat untuk diwawancarai. Akan tetapi dengan waktu yang singkat, penelitian ini telah memenuhi syarat-syarat penelitian ilmiah dan Peneliti menyadari bahwa kemampuan yang dimiliki sangat terbatas. Oleh karena itu, bimbingan dari dosen pembimbing yang dilakukan sangat membantu mengoptimalkan hasil penelitian ini.

Saran untuk perusahaan adalah untuk terus meningkatkan motivasi karyawan PT Wahyu Teknik Utama karena dengan tingkat motivasi yang tinggi dapat meningkatkan kinerja kerjanya, sehingga diperoleh karyawan yang memiliki semgangat kerja tinggi dengan hasil yang memuaskan perusahaan. Selanjutnya pemberian reward dalam rangka peningkatan kinerja karyawan PT. Wahyu Teknik Utama terbukti sangat berpengaruh dalam pengujian secara statistik, sehingga disarankan untuk memberikan reward yang adil dan objektif.

\section{REFERENSI}

Arifin et al., (2014). Organizational Culture, Transformational Leadership, Work Engagement and Teacher's Performance: Test of a Model. International Journal of Education and Research. 2: 1-14.

Brown. (2009). Increasing the Effectiveness of Reward Management. Brighton,Institute for Employment Studies.

Ghozali. (2011). Aplikasi Analisis Multivariate Dengan Program IBM SPSS 19. BP Universitas Diponegoro: Semarang.

Hidayat.(2018). Pengaruh Pemberdayaan Terhadap Kepuasan Kerja Melalui Komitmen Organisasional. Jurnal Organisasi dan Manajemen. Issue 1

Irawanti.(2016). Pengaruh Pemberian Reward dan Punishment terhadap Kinerja Karyawan (Studi Kasus Pada BMT Lima Satu Sejahtera Jepara). Semarang: Fakultas Ekonomi dan Bisnis Islam Universitas Negeri Walisongo.

Jayanti, Kurnia Tri, \& Wati, Lela Nurlaela. 2019. Pengaruh Gaya Kepemimpinan Terhadap Kinerja Karyawan Dan Dampaknya Terhadap Loyalitas Karyawan. Jurnal EKOBIS, Ekonomi, Bisnis \& Manajemen. Vol. 9. No. 1. Pp. 71-88.

Kurnia. (2016). Pengaruh Kompensasi dan Motivasi Kerja terhadap Kinerja Karyawan Rumah Sakit Condong Catur Yogyakarta. Universitas Negeri Yogyakarta. Yogyakarta

Moeheriono.(2010).Pengukuran Kinerja Berbasis Kompetensi. Rajawali Pers. Jakarta

Moorhead and Griffin. (2013). Perilaku Organisasi : Manajemen Sumber Daya Manusia dan Organisasi. Edisi 9. Salemba Empat. Jakarta.

Prasetya dan Kato. (2011). The Effect of Financial and Non Financial Compensation to the Employee Performance. International Research Symposium In Service Management Yogyakarta.

Robbins and Judge.(2012). Organizational Behavior. Pearson. Boston 
Robbins.(2009). Perilaku Organisasi.Salemba Empat. Jakarta

Simamora.(2014). Manajemen Sumber Daya Manusia. Bagian Penerbitan Sekolah Tinggi Ilmu Ekonomi YKPN. Yogyakarta

Sunyoto. (2013). Manajemen Sumber Daya Manusia, CAPS. Yogyakarta

Wijayanti dan Aldila.(2016). Pengaruh Penghargaan dan Motivasi Terhadap Kinerja Karyawan (Studi Pada Divisi Penjualan PT. United Motors Center Suzuki Ahmad Yani, Surabaya). Jurnal Ekonomi Bisnis dan Kewirausahaan, Vol. 5 No. 2.

Wati, L.N. (2018). Metodologi Penelitian Terapan, Aplikasi SPSS, EVIEWS, Smart PLS, dan AMOS. Edisi 2. Percetakan Pustaka AMRI: Jakarta 